\title{
PENDIDIKAN NILAI KEBERAGAMAAN DALAM \\ MEMBANGUN KEPRIBADIAN SEHAT \\ (Studi Deskriptif Analitik terhadap Siswa Madrasah Aliyah Darul \\ Arqam Muhammadiah Garut)
}

Dewi Sadiah

Fakultas Dakwah dan Komunikasi Universitas Islam Negeri Sunan Gunung Djati Bandung

\begin{abstract}
Potency of the high absorption obtained if learning in effective. Effective learning occurs when students are placed as individual active and direct contact with the subject matter.

This research aims to reduce the limitations of the tool (a computer or laptop) and maximizing existing facilities (hand phone) with the aim of achieving effective learning that puts students as subjects of learning.

This study is a research field for conducting comparative academic performance of two models of learning. The first learning model is simulation learning and the second model is self-learning via mobile facility. Self-learning materials in this research is the material in the form of video $3 \mathrm{GP}$ and transferred to the student's mobile. The research population is 85 students and a sample taken by 70 students. The data in this study is the performance of students from simulation learning model and self- learning model based 3GP video. Data analysis using Inferential statistical, namely the t-test. Data analysis was performed after the fulfillment of the requirements for normality of data.

The results of hypothesis testing obtained the results as following:

The value $t$ count bigger than $t$ table $(5.957>2.025)$. Thus $\mathrm{Ha}$ is received and Ho is rejected (significance below or equal to 0.05 so $\mathrm{Ha}$ is received). Means that there are significant differences between simulation learning model and self-learning model based 3GP video. Keywords: Learning Media, 3GP Video.
\end{abstract}

\section{Pendahuluan}

Pendidikan adalah usaha sadar dan terencana untuk mewujudkan suasana belajar dan proses pembelajaran agar peserta didik secara aktif mengembangkan potensi dirinya untuk memiliki kekuatan spiritual keagamaan, pengendalian diri, kepribadian, kecerdasan, akhlak mulia, 
serta keterampilan yang diperlukan dirinya, masyarakat, bangsa dan negara sesuai dengan Undang-Undang RI. No. 2 Tahun 2003 tentang Sistem Pendidikan Nasional (2003).

Proses pendidikan ditujukan untuk mengembangkan kepribadian sehat yang dimiliki manusia secara utuh dan menyeluruh. Orang-orang dengan kepribadian yang sehat dapat menyesuaikan dirinya dengan baik dan dapat mengaktualisasikan dirinya (self actualizing). Kondisi kepribadian sehat menurut Usman Najati mengistilahkan dengan kepribadian normal menurut Islam yakni kepribadian yang berimbang antara tubuh dan roh serta memuaskan kebutuhan-kebutuhan, baik untuk tubuh maupun roh (M.U. Najati, 2005: 379).

Kepribadian normal adalah memperhatikan tubuh, kesehatan tubuh, dan kekuatan tubuh serta memuaskan kebutuhan-kebutuhannya dalam batas-batas yang telah digariskan syariat. Dalam waktu yang bersamaan, juga berpegang teguh pada keimanan kepada Allah Swt., menunaikan peribadahan, menjalankan segala apa yang diridhai-Nya dan menghindari semua hal yang dapat mengundang murka-Nya. Jadi, pribadi yang mampu mengendalikan hawa nafsu dan syahwatnya adalah pribadi yang normal atau sehat. Faktor utama dalam penilaian suatu kepribadian, dalam pandangan al-Quran, adalah akidah dan ketakwaan, sesuai dengan firman Allah dalam Q. S. Al-Hujuraat/49:13 yang artinya: “...Sesungguhnya, yang paling mulia di antara kamu di sisi Allah ialah orang yang paling bertakwa. Sungguh Allah Maha Mengetahui dan Mahateliti."

Sementara karakteristik kepribadian sehat (healthy personality) dalam pandangan Hurlock (1974: 425), adalah ditandai dengan: (1) mampu menilai diri secara realistik; (2) menilai situasi secara realistik; (3) menilai prestasi yang diperoleh secara realistik; (4) menerima tanggung jawab; (5) kemandirian (autonomy); (6) dapat mengontrol emosi; (7) berorientasi tujuan; (8) berorientasi keluar; (9) penerimaan sosial; (10) memiliki filsafat hidup, dan; (11) berbahagia.

Tujuan Pendidikan Nasional dalam Undang-Undang RI. No. 20 Tahun 2003 tentang Sistem Pendidikan Nasional Bab II Pasal 3, adalah: Pendidikan Nasional berfungsi mengembangkan kemampuan dan membentuk watak serta peradaban bangsa yang bermartabat dalam rangka mencerdaskan kehidupan bangsa bertujuan untuk berkembangnya potensi 
peserta didik agar menjadi manusia yang beriman, bertakwa kepada Tuhan Yang Maha Esa, berakhlak mulia, sehat, berilmu, cakap, kreatif, mandiri, dan menjadi warga negara yang demokratis serta bertanggung jawab.

Rumusan tujuan Pendidikan Nasional tersebut di atas, yang dimaksud manusia seutuhnya yaitu manusia yang berakhlak mulia, berkepribadian sehat dapat diwujudkan apabila kepada yang bersangkutan atau peserta didik diberikan pendidikan agama yang merupakan bagian dari program pendidikan umum. Hal ini, sesuai dengan yang dikemukakan oleh Sumaatmadja (199: 26.), bahwa "Pendidikan umum sebagai program pendidikan yang diarahkan untuk membentuk manusia utuh menyeluruh yang meliputi manusia yang sangat belia sampai kepada manusia yang sudah tua yang diberikan melalui pendidikan sekolah maupun pendidikan luar sekolah."

Sedangkan manusia yang utuh menurut Abdul Mujib, yaitu "manusia utuh atau kepribadian yang utuh adalah gabungan antara dimensi-dimensi ragawi (biologis), kejiwaan (psikologi), lingkungan (sosio-kultural), dan ruhani (spiritual) yang memandang manusia dalam kesatuan utuh (Sumaatmadja, N., 1990: 26). Pandangan Najati (2005: 426), terkait hal tersebut khususnya adalah agama Islam, membantu memberikan buktibukti keberhasilan keimanan kepada Allah dalam menyembuhkan jiwa dari berbagai penyakit, mewujudkan perasaan aman dan tenteram, mencegah perasaan gelisah, serta berbagai penyakit kejiwaan yang adakalanya terjadi.

Nilai keberagamaan terdiri dari dua kata, yaitu kata nilai dan keberagamaan (Departemen Pendidikan Nasional, 2001: 783). Nilai adalah sifat-sifat (hal-hal) yang penting atau berguna bagi kemanusiaan, sedangkan keberagamaan yaitu perihal beragama dalam beribadat; keagamaan yaitu yang berhubungan dengan agama; agama ialah ajaran atau sistem yang mengatur tata keimanan (kepercayaan), peribadatan kepada Tuhan Yang Maha Kuasa, tata kaidah yang berhubungan dengan pergaulan manusia serta lingkungannya (Depdiknas, 2001: 12).

Jadi, nilai keberagamaan yang dimaksud dalam penelitian ini yaitu kegiatan menanamkan nilai tauhid, iman, Islam, ihsan, takwa, ikhlas, tawakkal, syukur, dan sabar. Dilihat dari segi tujuan yang hendak dicapai, pendidikan nilai keberagamaan dalam membangun kepribadian sehat diarahkan untuk membina perilaku anak yang lebih baik, menarik, menyenangkan hati, shaleh, menurut tuntunan Islam, yang memancarkan iman dan takwa. 
Jika melihat sejarah pendidikan Islam yang paling awal, bahwa sistem pendidikan Rasulullah Saw belum mengeluarkan pengakuan kelulusan melalui gelar atau ijazah. Nilai tertinggi murid-murid Rasulullah Saw., terletak pada tingkat ketakwaan. Ukuran takwa terletak pada akhlak dan amal shaleh yang dilakukan oleh masing-masing sahabat. Dengan demikian output sistem pendidikan Rasulullah Saw adalah orang yang langsung beramal, berbuat dengan ilmu yang didapat karena Allah kemudian dikembangkan oleh para sahabat, maka lahirlah generasi Islam terbaik (Antonio, M.S., 2009: 185).

Di Dar al-Arqam, Rasulullah mengajar tentang wahyu yang diterimanya kepada kaum muslimin dengan cara menghafal, menghayati, dan mengamalkan ayat-ayat suci yang diturunkan kepadanya (Munir, 1998: 198). Pandangan Antonio (2009: 185), bahwa tuntunan Muhammad Saw tentang sifat-sifat guru yang menjadi indikator kepribadian sehat yaitu: ikhlas, jujur, adil, akhlak mulia, tawadhu, berani, jiwa humor yang sehat, sabar dan menahan amarah, menjaga lisan, sinergi, dan musyawarah.

Sedangkan ditelaah dari sudut kajian pendidikan umum, nilai-nilai perilaku keberagamaan dalam membina kepribadian sehat merupakan salah satu kajian yang esensial, karena lebih banyak mengarah kepada terciptanya pengembangan atau pembinaan serta membangun kondisi kedewasaan dan kemandirian peserta didik, agar kehidupannya menjadi tenang, bahagia, harmonis, memiliki nilai-nilai yang prinsipil bagi kemanusiaan, dan kemanusiawian dalam pergaulan hidup bermasyarakat.

Kejadian yang sering muncul dalam tindakan siswa, yang bertolak belakang dengan nilai keberagamaan yang dididikkan, seperti timbulnya peralihan nilai bagi peserta didik menimbulkan persoalan tersendiri yang mengakibatkan munculnya gejala-gejala yang tidak diharapkan berupa merebaknya kemerosotan moral dewasa ini di kalangan remaja. Oleh karena itu, guna menghindari semakin rusaknya komitmen berkepribadian sehat, maka diperlukan pendidikan nilai keberagamaan dalam membina kepribadian sehat siswa yang bisa diimplementasikan di sekolah dan berdasarkan pada beberapa alasan yaitu:

1. Peranan guru agama terhadap pendidikan nilai keberagamaan dalam membangun kepribadian sehat, sangat mengkristal karena menekankan kepada perwujudan sikap, perilaku dan pribadi yang sehat, akhlak, 
mulia, beriman dan bertakwa kepada Allah Swt. Seorang guru harus menjadi idola bagi muridnya, sehingga setiap perkataan dan tingkah laku guru akan ditirunya (R. Megawangi, 2004: 161).

2. Orang tua siswa tidak ingin anaknya nakal, oleh karena itu anaknya dimasukan ke sekolah yang ada di lingkungan pesantren. Menurut Tafsir (2006: 10), orang tua tidak ingin anaknya nakal sekurangkurangnya ada empat alasan: (a) Remaja nakal itu kesehatan fisiknya terancam; (b) Remaja nakal itu prestasi akademiknya akan menurun; (c) Remaja nakal itu mahal; (d) Orang tuanya malu bila punya anak nakal. Ternyata tidak ada orang tua yang ingin punya anak nakal, karena malu, sekalipun orang tuanya nakal. Menurut Hawari (1999: 77), bahwa tawuran, penyalahgunaan obat terlarang, dan tindakan kriminal di kalangan remaja, disebabkan tidak adanya komunikasi yang baik antara keluarga, sekolah, dan masyarakat. Sehingga adanya nilai keberagamaan yang diajarkan di sekolah sebagai suatu konsep yang ideal, berhadapan dengan realita di masyarakat yang bertolak belakang dengan eksistensi pemahaman keberagamaan siswa di sekolah. Dalam keadaan demikian lahirlah sikap-sikap tertentu di kalangan siswa yang mencerminkan kegalauan nilai dan kebingungan arah, serta adanya kesenjangan antara pendidikan keagamaan yang diajarkan di sekolah dengan tingkat pemahaman nilai-nilai keberagamaan peserta didik.

3. Kepribadian sehat erat kaitannya dengan kepribadian utuh, yakni kepribadian mantap dan matang (dewasa) yang merupakan salah satu tujuan dari pendidikan umum. Sedangkan tujuan dari Pendidikan Nilai untuk membantu peserta didik agar memahami, menyadari, dan mengalami nilai-nilai serta mampu menempatkannya secara integral dalam kehidupan (R. Mulyana, 2004: 119). Untuk sampai pada tujuan dimaksud, tindakan-tindakan pendidikan yang mengarah pada perilaku yang baik dan benar perlu diperkenalkan oleh para pendidik. Sementara UNESCO (1992: 19), mengkatagorikan bahwa tujuan Pendidikan Nilai meliputi tindakan mendidik yang berlangsung mulai dari usaha penyadaran nilai sampai pada perwujudan perilaku-perilaku yang bernilai atau bermakna.

4. Ketertarikan adanya keberhasilan yang dilakukan oleh para pengelola Ma'had Darul Arqam Muhammadiyah Daerah Garut Jawa Barat, 


\section{Dewi Sadiah}

menunjukkan sekolah yang berbeda dengan sekolah umum yang ada di lingkungan pesantren lainnya. Kebijakan Ma'had Darul Arqam Garut (2008: 6), sebagaimana yang dituangkan dalam aturan penyelenggaraan pendidikan, diarahkan untuk terciptanya (sukses belajar mengajar, sukses berprestasi, dan berprestise, sukses kaderisasi organisasi) kehidupan dan keadaan yang tertib, aman, nyaman, sejahtera, dan memberikan arahan bagi terciptanya situasi tertentu terhadap lembaga pendidikan. Penyediaan sarana pendidikan dan fasilitas sekolah ditata searah dengan visi dan misi yang diemban sekolah, di antaranya menyelenggarakan dan mengembangkan model-model pembinaan dan pengkaderan serta kegiatan dakwah islamiah, sehingga memberikan iklim tersendiri dalam seluruh konteks pendidikannya.

\section{Hasil Penelitian dan Pembahasan}

Deskripsi dan hasil pembahasan yang menganalisis data hasil penelitian, sebagai berikut:

1. Tujuan pendidikan yang diharapkan oleh guru agama membangun kepribadian sehat siswa di sekolah dapat diinterpretasikan bahwa upaya guru agama telah diwarnai oleh faktor-faktor internal dan faktor eksternal. Segala upaya yang dilakukan oleh guru agama dalam membangun kepribadian sehat dan akhlak yang baik, sudah mengarah kepada pencapaian satu tujuan yaitu manusia memiliki kepribadian utuh atau insan yang sehat, dalam arti selamat di dunia dan di akhirat.

Adapun upaya yang dilakukan oleh guru agama berupa pembinaan dalam melaksanakan ibadah-ibadah mahdhah yang hukumnya wajib (shalat Subuh, Dzuhur, Ashar, Magrib, dan Isya secara berjamaah), maupun ibadah yang hukumnya sunat (shalat tahajjud, puasa hari senin dan kamis, mendengarkan adzan dengan khidmat, mengucapkan salam, berdoa, tadarus al-Quran, dan tahfizh ayat-ayat al-Quran). Dalam mencapai tujuan tersebut, mereka lakukan berulang-ulang dengan penuh rasa tanggung jawab dan komitmen yang cukup kuat, walaupun dengan cara pendekatan yang berbeda dalam menampilkan perilakunya, akan tetapi tujuan tetap menjadi harapan bersama sebagai sesuatu yang ingin dicapai. 
Pembinaan kepribadian sehat terhadap siswa yang dilakukan oleh guru agama, merupakan alat untuk membantu mereka dalam melaksanakan tata cara hidup sehari-hari, yang mencakup hablum minallah dan hablum minannas, akhirnya tercipta kehidupan yang damai, selalu berusaha menempatkan diri dalam lingkungan baik di sekolah maupun masyarakat, sehingga disenangi dalam pergaulan sehari-hari.

Hasil wawancara dengan tiga orang guru agama di Madrasah Aliyah Darul Arqam Garut menunjukkan bahwa pembinaan kepribadian sehat siswa di sekolah, agar semua siswa mempunyai tujuan hidup yang islami sebagai pedoman hidup di dunia dan bekal hidup kelak di akhirat, berakhlak yang terpuji, beriman dan bertakwa kepada Allah, berbakti kepada kedua orang tua, sopan dalam berbicara, santun dalam bertindak, menghargai teman sebaya dan sayang kepada yang lebih muda. Al-Quran diturunkan kepada manusia sebagai makhluk yang memerlukan komunikasi (S. Sauri: 2009: 29). Kemudian kalau dikaitkan dengan pendidikan nilai keberagamaan dalam membangun kepribadian sehat, tujuan pendidikan pada dasarnya ditentukan oleh pandangan hidup (way of life) orang yang mendesainnya, yaitu menjadi manusia terbaik menurut pandangan Allah (A. Tafsir: 2006: 75).

Adapun menurut guru, bahwa tujuan pendidikan adalah dengan menyadari potensi yang dimiliki manusia Ma'had Darul Arqam Garut berusaha untuk memaksimalkan potensi siswa dan membimbingnya agar menjadi anak yang shaleh dan insan yang dicintai Allah Swt. Kemudian tentang ketaatan kepada Allah terungkap sebagai tujuan guru agama dalam membina kepribadian sehat atau akhlak siswa. Adapun pribadi sehat mengandung pengertian sehat atau kesehatan di sini menurut Undang-Undang No.23 Tahun 1992 tentang kesehatan, di mana kesehatan tersebut mencakup 4 aspek: aspek fisik (badan), aspek mental (jiwa), sosial, dan aspek ekonomi (Kusuma A, 20 Desember 2010).

Tujuan tersebut, salah satunya dapat direpleksikan dalam perilaku guru pembina ketika mengajak siswa untuk melaksanakan shalat berjamaah tepat waktu dan bimbingan baca tulis al-Quran lengkap dengan penafsirannya secara sungguh-sungguh. Makna yang terkan- 


\section{Dewi Sadiah}

dung dari kegiatan guru dan siswa tersebut adalah: Makna nilai ketaatan, nilai kesungguhan dan nilai kejujuran. Nilai kesungguhan dan nilai ketaatan terungkap pada saat mngucapkan dan melakukan bacaan yang sudah diatur dan dicontohkan dalam shalat.

Untuk menyatakan kesungguhan dalam shalat perlu adanya pengucapan bacaan shalat yang benar, penghayatan, menghadirkan Allah dalam perasaan sedang shalat seolah-olah tampak berhadapan sedang memperhatikan. Adapun nilai kejujuran terungkap dengan melakukan semua aturan dalam shalat tidak mengurangi dan tidak melewati petunjuk pelaksanaan shalat yang dimulai dari takbiratul ihram dan diakhiri dengan salam.

2. Metode yang digunakan guru agama dalam membangun kepribadian sehat yaitu: Metode keteladanan untuk mempengaruhi siswa dengan penampilan guru agama dan guru umum sebagai sosok yang patut diteladani. Mereka secara tidak langsung telah membimbing siswa dalam mengaplikasikan pendidikan nilai keberagamaan dalam membina kepribadian sehat dengan baik melalui teladan Rasulullah Saw, disiplin waktu, ketaatan beribadah, kebersihan, keindahan penataan fisik sekolah, penampilan berpakaian, perhatian, nasihat yang baik, dan pembiasaan. Yang demikian itu, mereka lakukan agar bisa diteladani oleh siswa untuk melakukan hal yang baik.

Sebagaimana Said (1994: 151), menyatakan bahwa kecintaan yang tulus terhadap Rasulullah Saw selaku guru dan pendidik dengan dilandasi oleh petunjuk Allah Swt., untuk mencintai dan mentaatinya, para sahabat menjadi orang-orang yang sangat berambisi untuk mengikuti jejak langkahnya sang panutan Rasulullah Saw. Abu Bakar Ash-Shiddiq ra berkata: "Aku tidak meninggalkan sesuatu pun. Semua yang dikerjakan Rasulullah Saw, aku mengerjakannya, aku takut akan terpeleset jika meninggalkan sesuatu dari yang pernah beliau perintahkan”.

Adapun metode keteladanan yang mereka lakukan selalu disesuaikan dengan konteksnya, misalnya, sewaktu suara adzan berkumandang semua siswa mendengarkan dengan khidmat sampai selesai. Selanjutnya pada saat istirahat guru dan para siswa melaksanakan shalat berjamaah Subuh, Dzuhur, Ashar, Magrib, dan Isya di masjid sambil mendengarkan ceramah yang dilaksanakan oleh para siswa secara 
bergiliran. Ketika siswa ada masalah maka segera diselesaikan sampai tuntas baik di sekolah, di asrama, maupun di masjid, dan lainnya.

Siswa yang tidak melaksanakan shalat berjamaah diberi sanksi, sebelumnya diberi peringatan dulu, akhirnya siswa yang belum melaksanakan shalat berjamaah merasa sadar dan terketuk hatinya untuk segera melaksanakan shalat berjamaah. Selain keteladanan seperti di atas, semua siswa di saat masuk dan keluar meninggalkan kelas selalu mengucapkan salam. Keteladanan lain terlihat dari perilaku guru agama yang selalu datang lebih awal atau tepat waktu, dengan pakaian dan penampilan rapi serta berlaku adil. Begitu juga peserta didik mencontoh apa yang guru kerjakan dalam menjaga kebersihan tidak membuang sampah sembarangan. Upaya lain dalam menanamkan kedisiplinan diterapkan pada kegiatan keberagamaan terutama mengenai waktu, sering diungkapkan ARg yaitu pandaipandailah menggunakan waktu.

Adapun peraturan tata tertib dalam menjaga kesopanan yang dibuat Madrasah Aliyah Darul Arqam Garut dilaksanakan dengan kerelaan hati yang ikhlas. Sementara metode guru agama melalui nasihat yang baik untuk mempengaruhi siswa menjadi manusia yang berkepribadian sehat, ternyata dilakukan tidak hanya terbatas dalam konteks rutinitas kegiatan yang sudah berlabelkan agama saja, akan tetapi dilakukan juga pada setiap kesempatan dalam segala bentuk kegiatan kehidupan baik dalam situasi formal di kelas, di masjid, di asrama, atau di luar kelas. Dengan cara dan situasi demikianlah guru mata pelajaran agama dan guru mata pelajaran umum, memberikan keteladanannya sehingga tercipta iklim yang kondusif bagi pengembangan pribadi siswa yang berkepribadian sehat.

Dalam mempertahankan nilai-nilai religius siswa di sekolah, melalui nasihat yang baik ternyata dilakukan secara menyeluruh di antaranya: mencakup seluruh kondisi kehidupan, aneka peristiwa alam semesta, dan fenomena-fenomena kekuasaan-Nya serta karunia Allah Swt. Guru agama (ARg) terbiasa memberikan nasihat diselingi dengan humor dan tanya jawab, ketika melihat muridnya merasa jenuh dengan pelajaran yang banyak atau murid yang tidak bisa mengerjakan tugas yang diberikan oleh guru. 
Dari pengamatan di lokasi penelitian, nilai dasar yang hendak dicapai adalah nilai ketuhanan, pemberian nasihat yang baik lebih dipahami sebagai ikhtiar untuk menciptakan iklim yang kondusif bagi pengembangan pribadi manusia yang berkepribadian sehat, berakhlak mulia, beriman dan bertakwa kepada Allah Swt. Cara pemberian nasihat yang baik dimaksudkan juga untuk mengingatkan kembali kepada para siswa tentang apa yang menjadi tanggung jawabnya sebagai muslim sejati.

Dengan cara tersebut guru agama bermaksud mengajak siswa agar melakukan apa yang dipesankannya dan bukan hanya sekedar membina atau membangun akhlak dan perilaku siswa saja, melainkan juga untuk membina suasana nilai kebersamaan dalam kehidupan sekolah, menampakkan kepedulian guru terhadap permasalahan yang dihadapi siswa, sehingga siswa dapat melakukan perbuatan disiplin dan bertanggung jawab sebagai perwujudan sosok manusia yang berkepribadian sehat yang insan kamil.

Perhatian guru mata pelajaran agama dan guru mata pelajaran umum dengan cara melontarkan pertanyaan-pertanyaan kepada siswa tidak hanya bermakna komunikasi lisan semata, tetapi mengandung makna yang lebih penting yaitu adanya perhatian dan kepedulian guru yang sangat mendasar dengan mengingatkan kembali kepada siswa akan tugas-tugas yang mereka emban sebagai hamba Allah yang selalu beribadah kepada-Nya. Dengan bertanya, guru agama kepada siswanya berarti telah mengingatkan siswa agar selalu ingat tugas dan kewajiban selaku siswa mengetahui apa yang menjadi permasalahan yang sedang dihadapi para peserta didiknya, sehingga dapat membantu dan mengatasi dalam menyelesaikan pelbagai permasalahannya.

Atas dasar perhatian dan pemahaman terhadap keadaan dan latar belakang yang menjadi persoalan siswa tindakan guru akan lebih terarah dan tepat sasaran dalam memecahkan persoalan yang dimiliki siswa. Melalui perhatian, berarti para guru telah saling menasehati, mengingatkan, dan mentaati suatu kebenaran dan kesabaran yang merupakan wujud kepedulian sosok manusia yang berkepribadian sehat (Q.S. al-Ashr/103: 3).

Dengan berbagai kegiatan yang dilakukan guru agama baik dalam konteksnya yang berkenaan langsung dengan nilai-nilai akhlak atau 
kepribadian sehat siswa dan cara mengkaitkannya dengan nilai-nilai akhlak terhadap Allah, akhlak terhadap manusia dan lingkungannya, jelas memperlihatkan bahwa pembiasaan yang dilakukan guru agama dan guru umum sangat mempengaruhi pertumbuhan perilaku siswa dari kurang baik menjadi baik, dan dari baik menjadi lebih baik. Keteguhan pribadi guru agama dan guru umum telah mendorong mereka untuk menciptakan pembiasaan dalam bentuk realisasi program kegiatan ekstrakurikuler keberagamaan yang ditindaklanjuti oleh para siswa.

Dalam kegiatan tersebut guru agama tampak memasilitasi kesempatan siswa untuk berbuat sesuai dengan kapasitasnya, namun tetap dalam perhatian sebagaimana mestinya. Dalam situasi seperti tersebut di atas, pembiasaan yang dilakukan guru agama akan menjadi titik awal perbuatan siswa untuk lebih meningkatkan: Ketaatan terhadap Allah, penampilan berpakaian yang rapi dan bersih, kedewasaan, kemandirian, kekeluargaan yang harmonis, peningkatan pengetahuan dan keterampilan, tatakrama dan kesopanan. Perubahan tersebut terlihat pada siswa kelas XI dan kelas XII sedangkan pada kelas X masih kurang perubahannya yang pada akhirnya akan menjadi kebiasaan dalam perilaku siswa yang kepribadian sehat dan berakhlak mulia.

3. Pada aspek kurikulum, kurikulum yang digunakan guru agama dalam membangun kepribadian sehat yaitu Kurikulum Tingkat Satuan Pendidikan (KTSP) Ma'had Madrasah Aliyah Darul Arqam Garut yang memiliki kurikulum khusus pesantren. Kurikulum yang digunakan oleh guru agama dilihat dari substansinya lebih berupaya dalam pembinaan akhlak yang mulia dan kepribadian sehat serta kesetiakawanan sosial siswa. Seperti yang disampaikan oleh seorang guru, salah satu upaya sekolah untuk meningkatkan keimanan dan ketakwaan, akhlak siswa yang baik, yang memiliki kepribadian sehat agar lebih mampu dan teraplikasi dalam kehidupan nyata adalah melalui bimbingan agama di pesantren, sekolah, keluarga, masyarakat, dan mengembangkan spiritualitas melalui doa serta amalan-amalan nyata dalam bentuk aksi sosial.

Dalam mencapai keseimbangan antara pelajaran-pelajaran agama dan pelajaran-pelajaran umum keduanya sama-sama dibelajarkan untuk mengembangkan pendidikan dan pengajaran secara komprehensif 


\section{Dewi Sadiah}

yang mengintegrasikan sains-religious (al-Ulum al-Naqliyah) dan sains-rasional (al-Ulum al-Aqliyah). Menyelenggarakan pendidikan khusus kepesantrenan dalam penguasaan al-Ulum al-Naqliyah melalui pendidikan bahasa Arab, bahtsul kutub, dan kemuhammadiyahan.

Dalam melaksanaan kurikulum yang banyak, tentu memerlukan pengaturan waktu belajar yang efektif dan efesien, dengan ketentuan murid atau santri belajar setiap hari dimulai pada pukul 05.00 pagi sampai dengan pukul 09.00 malam, istirahat (untuk makan siang yang telah tersedia di sekolah, shalat berjamaah pada waktu Shubuh, Dhuhur, Ashar, Maghrib, dan Isya, ditambah shalat Tahajjud dan sunah lainnya, serta kegiatan lain yang langsung dibimbing oleh guru Pembina. Setiap hari sebelum shalat berjamaah para santri selalu bertadarus Al-Quran.

Pada jam pertama sekolah dimulai biasanya diawali dengan pembacaan ayat suci Al-Quran secara bersama-sama yang dipimpin oleh seorang siswa dan lamanya berdoa antara 5 s.d 10 menit. Sedangkan dalam penyempurnan tata tertib sekolah dengan menambahkan beberapa point yang bernilai islami seperti; membiasakan berpakaian sopan dan menutup aurat khususnya bagi santri perempuan dan diusahakan siswa datang ke ruangan kelas tepat waktu. Bagi siswa yang berprestasi diberikan reward berupa beasiswa dan hadiah-hadiah lainnya dan bagi siswa yang melanggar aturan Ma'had diberikan hukuman (punishment).

Para siswa dibiasakan untuk memberikan sedekah semampunya kepada orang yang tidak mampu, hal tersebut karena adanya itikad baik dari para pelaku pendidikan. Secara formal, pelaksanaan kurikulum yang dijadikan acuan kebijakan oleh guru agama di Madrasah Aliyah Darul Arqam Garut menerapkan pada kurikulum (KTSP) tahun pelajaran 2009/2010. Pelaksanaan tersebut, dengan maksud untuk mewujudkan manusia yang berkepribadian sehat, berakhlak mulia, beriman dan bertakwa kepada Allah Swt., sebagaimana yang tertera dalam tujuan pendidikan nasional.

Strategi pembelajaran yang diterapkan oleh guru agama bersama guru umum, pada kelas $\mathrm{X}$ dan XI yaitu agar bisa mengembangkan pengajaran sesuai dengan harapan dan arah tujuan sekolah namun pada siswa kelas XII guru agama secara optimal melakukan upaya 
pencapaian target kurikulum dengan jalan bimbingan belajar intensif mengikuti kegiatan bimbingan belajar (bimbel) dengan Primagama, Ganesa Operation, dan Nurul Falah adapun materinya yang di-UNkan dengan maksud untuk mempersiapkan peserta didik ke jenjang Perguruan Tinggi.

Orientasi dari pelaksanaan kurikulum pesantren, adalah untuk memodifikasi model pesantren sebagai suatu pendidikan yang memiliki arah agar manusia sebagai makhluk yang diberikan potensi akal, dapat mengembangkan akhlak yang mulia dan memiliki kepribadian sehat, melalui pendidikan nilai keberagamaan secara formal dengan mempertimbangkan masalah situasi dan kondisi sosial masyarakat untuk mengoptimalkan mutu lulusan sebagai insan yang sehat, beriman dan bertakwa kepada Allah Swt.

Eksistensi guru agama dan guru pembina dalam meningkatkan kualitas siswa melalui kebijakan kurikulum yang mengacu kepada tujuan Pendidikan Nasional. Secara operasional wawasan kurikulum tersebut dilaksanakan agar materi yang diajarkan di Madrasah Aliyah Darul Arqam Garut adalah untuk mencapai harapan prestasi akademis yang optimal. Namun, dalam pelaksanaannya kurikulum Madrasah Aliyah Darul Arqam Garut lebih ditekankan pada aplikasi nilainilai keberagamaan dalam kehidupan siswa sehari-hari, di samping menguasai sejumlah materi-materi yang ada pada kurikulum.

Dalammembinadanmemantaupelaksanaanprogramekstrakurikuler yang dilakukan oleh guru pembina dengan tujuan agar siswa dalam kebebasan memilih kegiatan ekstrakurikuler tersebut tetap senantiasa terarah dan dalam bingkai akhlak mulia yang memiliki kepribadian sehat. Dilihat dari komposisi kecenderungan produk Madrasah Aliyah Darul Arqam Garut boleh dikatakan memiliki potensi yang mampu berkompetisi dengan lembaga pendidikan sederajat. Madrasah Aliyah Ma'had Darul Arqam Garut telah memperoleh berbagai prestasi yang telah diraihnya baik dari cabang olah raga maupun prestasi akademik.

Adapun program ekstrakurikuler yang sangat mendukung terhadap kegiatan pendidikan nilai keberagamaan dalam membina kepribadian sehat ada tiga program kegiatan esktrakurikuler yaitu: (1) IPM (Ikatan Pelajar Muhammadiyah) yang membawahi departemen Kajian dan 
Dakwah Islam, Kaderisasi dan pengembangan Sumber Daya Manusia, Apresiasi seni budaya dan olahraga, Korps Ilmiah Remaja, Korps Mubaligh Remaja, Korps Qoriah Remaja, Korps Nasid Remaja, Pengkajian Ilmu Pengetahuan; (2) HW (Huzbul Wathan), dan; (3) Tapak suci. Semua sivitas akademika menurut NHg perlu adanya kerjasama dari berbagai pihak atau program yang satu dengan pogram lainnya, sehingga bisa saling melengkapi dalam berbagai hal.

Dalam membina kepribadian sehat atau akhlak siswa di Madrasah Aliyah Darul Arqam Garut yang dilakukan oleh guru agama tidak lepas dari kurikulumnya. Secara umum kurikulum yang dijadikan rujukan adalah: Kurikulum Tingkat Satuan Pendidikan (KTSP) yang dilengkapi dengan program ekstrakurikuler dan tata tertib sekolah. Kurikulum Ma'had Darul Arqam (2008: 18), yang bersifat "berimbang" dan "terpadu". Kegiatan yang bersifat ekstrakurikuler adalah sarana penunjang untuk memunculkan semua potensi yang dimiliki santri.

Dengan adanya kurikulum yang dijadikan acuan kebijakan Madrasah Aliyah Darul Arqam Garut dalam melahirkan kebijakan operasional pendidikan nilai keberagamaan dalam membangun kepribadian sehat atau akhlak terhadap siswa memiliki dasar hukum yang kuat dan dapat dibenarkan. Keseluruhan program pendidikan yang ada berupaya untuk mengoptimalkan pengembangan potensi siswa secara menyeluruh (holistik) yang dilakukan baik di sekolah atau di luar sekolah. Keseimbangan dalam mengembangkan potensi dasar manusia berarti menjadikan potensi yang harus dikembangkan untuk mencapai tujuan yang lebih tinggi yakni insan kamil (A. Tafsir, 1990: 13).

4. Pendidikan nilai-nilai keberagamaan dalam membangun kepribadian sehat terhadap perubahan perilaku siswa yang ditampilkan oleh guru agama dalam wujud ucapan, pikiran, dan tindakan telah membawa hasil yang tampak dalam perilaku keseharian siswa di lingkungan sekolah. Hal tersebut membuktikan bahwa sosok guru agama telah berhasil dalam membangun iklim yang kondusif bagi siswa dalam mengembangkan dirinya dan memupuk semangat beragama.

Dari penampilan guru agama dan guru umum yang demikian adanya, maka lahir perilaku siswa yang menurut hasil pengamatan mereka selain melakukan ibadah-ibadah yang wajib (shalat berjamaah 
Subuh, Dzuhur, Ashar, Magrib, dan Isya) juga ibadah sunat seperti shalat sunat rawatib, shalat Tahajjud, Dzuha, puasa hari Senin dan Kamis, dan lainnya yang secara moralitas dapat dijadikan indikator penunjuk tingginya kesadaran beragama.

Menurut guru pembina, yang dirasakan selama ini, kalau mengajar di sekolah untuk santri putri tidak terasa lelah, tetapi kalau mengajar di sekolah untuk santri putra terasa lelah sekali. Sementara contoh nilai kesadaran masih adanya santri yang suka menutupi kesalahan temannya, karena solidaritas nilai kebersamaannya sangat kuat. Ketika ada pemeriksaan tentang santri yang membawa hp, kalau ketahuan santri membawa hp oleh guru pembina, maka hpnya dikembalikan kepada orang tuanya selama 1 tahun. Kemudian apabila mau ulangan di kelas ada santri yang pura-pura sakit karena tidak siap untuk mengikuti ulangan hari itu, seharusnya santri jujur saja sehingga santri tersebut bisa mengadakan perubahan untuk bisa mengatasi ulangan-ulangan berikutnya dan kasus-kasus lainnya.

Seandainya nilai disiplin dan kesadaran (termasuk shalat berjamaah) dioptimalkan atau ditegakkan dengan tegas dalam sebuah pembinaan khususnya di Madrasah Aliyah Darul Arqam baik aturan maupun sanksi yang membuat jera atau sadar bagi santrinya, semua itu akan terpancar sifat siddiq dalam pribadi peserta didik dan menjadi keberhasilan yang luar biasa untuk masa depan siswa/santri sebagai kader ulama di masa yang akan datang. Berdasarkan wawancara dengan kepala sekolah Darul Arqam Garut dengan banyak belajar menghasilkan berbagai prestasi. Apalagi yang berprestasi di Darul Arqam Garut bisa mengikuti pertukaran siswa ke luar negeri (USA), beasiswa santri berprestasi dari Depag dan beasiswa dari Perguruan Tinggi Negeri.

\section{Simpulan dan Saran}

\section{Simpulan}

Hasil penelitian tentang pendidikan nilai keberagamaan dalam membangun kepribadian sehat agar para siswa mentaati segala perintah Allah dan menjauhi segala larangan-Nya untuk mencapai keselamatan dunia dan akhirat, searah dengan visi \& misi Madrasah Aliyah Darul Arqam Garut dan tujuan pendidikan nasional, serta direalisasikan dalam 
bentuk ketaatan kepada Allah Swt., berbakti kepada kedua orang tua, hormat kepada guru, saling berbuat baik terhadap teman, berperilaku disiplin, cinta ilmu pengetahuan, jujur, sabar, kasih sayang, ikhlas, dan pemaaf untuk mencapai insan yang sehat.

Siswa mampu berakidah yang benar, khusyu dalam ibadah, memiliki berkepribadian yang sehat, mencontoh tuntunan Nabi Muhammad Saw, pandai bermasyarakat, memiliki kebebasan berpikir, dan berperan aktif dalam berorganisasi. Adapun metode yang digunakan guru agama dalam pembelajaran keteladanan, nasihat yang baik dengan penuh kasih sayang, perhatian, dan pembiasaan.

Dilengkapi dengan kurikulum MA Darul Arqam yang bersifat "Berimbang" dan "Terpadu" antara pelajaran agama dan pelajaran umum. Hasil yang dicapai adanya perubahan perilaku siswa dari kurang baik menjadi baik dan dari baik menjadi lebih baik. Maka perubahan tersebut, dapat bercermin pada karakteristik Rasulullah Saw., yaitu : siddiq, amanah fatonah, dan tabligh yang direalisasikan oleh nilai-nilai keberagamaan siswa di sekolah dengan menanamkan nilai-nilai: tauhid atau keimanan, Islam, ihsan, takwa, ikhlas, tawakkal, syukur, dan shabar ini semua terbukti mereka rajin melaksanakan ibadah mahdhah maupun ibadah ghoir mahdhah, sehingga melahirkan keshalehan sosial menuju insan yang sehat.

Adapun hasil temuan penelitian di Madrasah Aliyah Ma'had Darul Arqam Muhammadiyah Garut: 


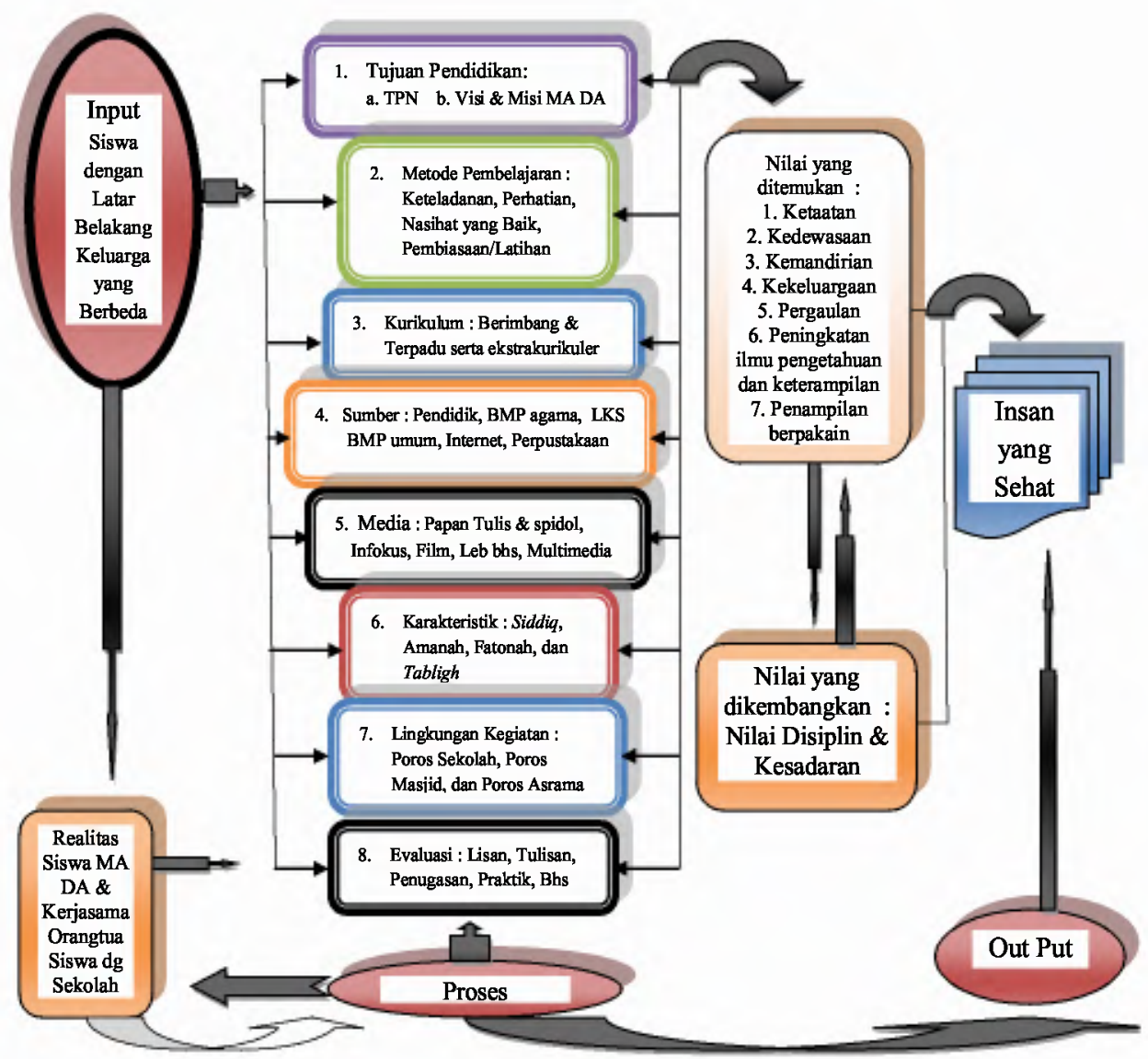

\section{Saran}

Beberapa saran yang dapat penulis berikan berkaitan dengan hasil penelitian ini adalah: (a) Belum adanya pendidikan nilai keberagamaan dalam membangun kepribadian sehat, maka penting untuk diterapkan di Madrasah Aliyah Darul Arqam Muhammadiyah Garut; (b) Sistem pendidikan nilai keberagamaan dalam membangun kepribadian sehat dapat dijadikan masukan bagi SMA/SMK/MA dari aspek-aspek keunggulan yang terjadi di tempat penelitian. Semua pihak yang terkait di MA DA Garut harus memiliki inisiatif dalam mencari alternatif kegiatan-kegiatan yang dapat dibakukan di sekolah, pengelolaan masjid dan kegiatan keagamaan lebih banyak dipercayakan kepada para siswa, serta sanksi atau punishment harus ditegakkan dengan tegas terutama nilai disiplin dan nilai 
kesadaran sehingga siswa menyadari dengan benar akan kesalahannya; (c) Pendidikan nilai keberagamaan dalam membangun kepribadian sehat ini, masih merupakan model yang belum diujicobakan di Madrasah Aliyah atau SLTA lainnya, tetapi dalam pelaksanaannya telah berhasil mewujudkan perubahan perilaku keberagamaan siswa di Madrasah Aliyah Darul Arqam Muhammadiyah Garut.

\section{Daftar Pustaka}

Mujib, Abdul. (1999). Fitrah \& Kepribadian Islam; Sebuah Pendekatan Psikologis. Jakarta: Darul Falah.

Antonio, M.S. (2009). The Super Leader Super Manager. Jakarta: Tazkia Publishing \& Pro-LM Centre.

Departemen Agama RI. (1999). Al-Quran dan Terjemahannya. Jakarta: Sari Agung.

Departemen Pendidikan Nasional. (2001). Kamus Besar Bahasa Indonesia. Jakarta: Balai Pustaka.

Djahiri, K. (1996). Menelusuri Dunia Afektif Pendidikan Nilai dan Moral. Bandung: Laboratorium Pengajaran PMP IKIP Bandung.

Hawari, D. (1999). Konsep Penanganan Perilaku Menyimpang Remaja. Dalam Syahrudin, D. 1999. Mari Bersatu Memberantas bahaya Penyalahgunaan Narkoba. Jakarta: BP. Dharma Bakti dan Yayasan penerus Nilai-nilai Luhur Perjuangan 1945.

Hurlock, B.E. (1974). Personality Development. New York: McGraw-Hill Book Company.

Kusuma, A (2009). Pengertian Sehat. Dari http://afand.abatasa.com/post/ detail/2456 diunduh 20 Desember 2010.

Ma'had Darul Arqam. (2008). Profil Sekolah Kader Muhammadiyah. Ma'had Darul Arqam Garut: Restu Budaya Parahyangan.

Megawangi, R. (2004). Pendidikan Karakter. Jakarta: Star Energy (Kakap) Ltd. 
Pendidikan Nilai Keberagamaan Dalam Membangun Kepribadian Sehat

Mulyana, R. (2004). Mengartikulasikan Pendidikan Nilai. Bandung: Alfabeta.

Mulyana, R dkk. (1999). Cakrawala Pendidikan Umum: Suatu Upaya Mempertegas Body of Knowledge. Bandung: IMA-PU PPs IKIP Bandung.

Munir, G. (1998). Al-Tarbiyyah al-Qiyadiyyah. Kairo: Dar al-Wafa.

Najati, M.U. (2005). Psikologi dalam Al-Quran Terapi Quran dalam Penyembuhan Gangguan Kejiwaan. Bandung: Pustaka Setia.

Said, M.R. (1994). Rasulullah Saw Profil Seorang Pendidik. Jakarta: Firdaus.

Sauri, S. (2009). Membangun Profesionalisme Guru Berbasis Nilai Bahasa Santun Bagi Pembinaan Kepribadian Bangsa yang Bijak. Pidato Pengukuhan Guru Besar dalam Bidang Pengajaran Bahasa Arab Berbasis Nilai pada Fakultas Pendidikan Bahasa dan Seni UPI Bandung.

Sumaatmadja, N. (1990). Konsep dan Eksistensi Pendidikan Umum. Bandung: FPS IKIP Bandung.

Tafsir, A. (1990). Pendidikan Iman dan Takwa; Kurikulum, Makalah Seminar Imtak di IAIN SGD Bandung.

Tafsir,A. (2006). Filsafat Pendidikan Islam. Bandung: Remaja Rosdakarya.

UNESCO. (1992). Education For Affective Development. Bangkok: Principal Regional Office for Asia and The Pasific.

Undang-Undang RI. No. 20 Tahun 2003. Sistem Pendidikan Nasional. Bandung: Fokusmedia. 